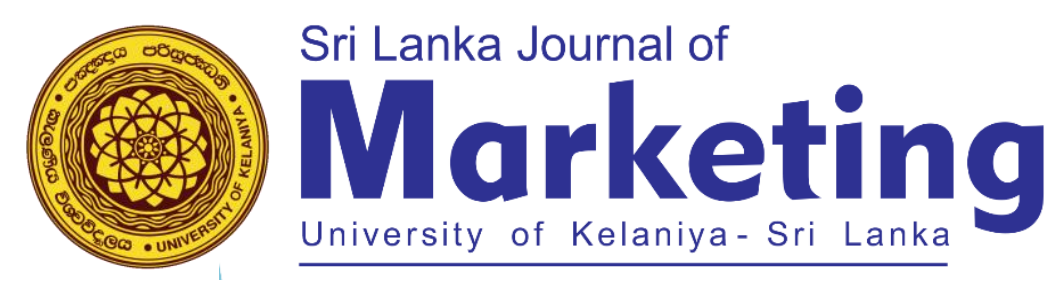

\title{
Entrepreneurial Marketing Dimensions: Evidence from Women-Owned SMEs in Sri Lanka
}

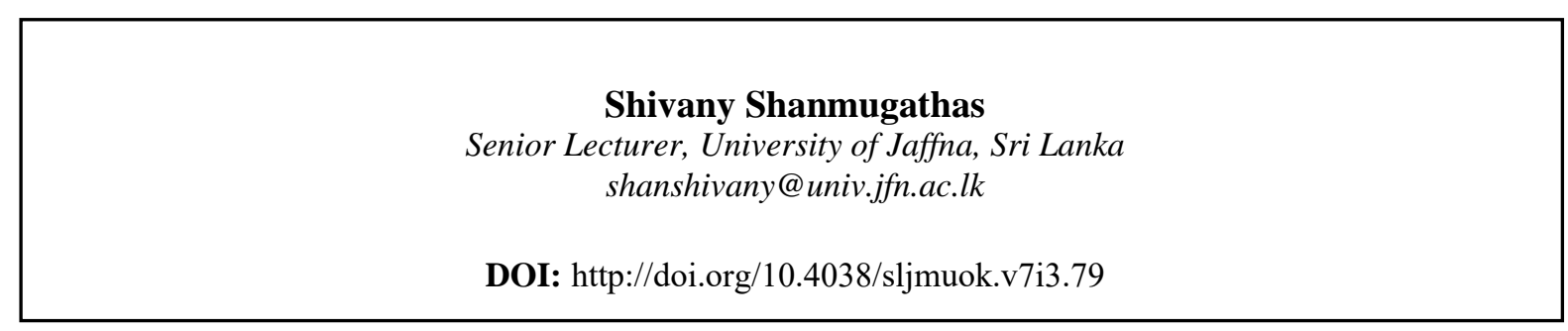

\section{ABSTRACT}

Women-owned SMEs have an enormous contribution to the economic development of Sri Lanka, which experienced 30 years of conflict, created numerous micro and small enterprises as the livelihoods of women-headed families. Since the entrepreneurial marketing (EM) approaches are new practices followed by numerous SMEs worldwide, this study intended to explore how these women-owned SMEs in Sri Lanka practice entrepreneurial dimensions for their marketing benefits. This study meant to discrete entrepreneurial marketing thoughts in women-owned SMEs and distinguished how current approaches seem steady through the entrepreneurial marketing benefits. The considerable inspiration in this study derived from how new evaluation of entrepreneurial marketing from the perspective of women-owned SMEs has gotten insufficient consideration in the critical literature. This study has been feasible with qualitative research with 49 women-owned SMEs in five districts of Sri Lanka. This study has collected primary data through an in-depth interview method. Thematic analysis was employed to analyze and interpret the seven fundamental dimensions of entrepreneurial marketing. Results show that even though the women-owned SMEs in Sri Lanka do not have professional marketing knowledge, they apply entrepreneurial marketing practices as similar approaches mentioned in the literature to succeed in their businesses. The findings of this study conveyed that entrepreneurial marketing practices have incredible significance for women-owned SMEs in Sri Lanka. Future research can empirically prove the seven dimensions of entrepreneurial marketing through a considerable sample size from other districts with cultural differences.

Keywords: Dimensions, Economic Development, Entrepreneurial Marketing, Women-Owned SMESs

ORCID of authors: Shivany Shanmugathas - (D) https://orcid.org/0000-0001-9820-2695

Copyright: This is an open access article distributed under the Creative Commons Attribution License 4.0, which permits unrestricted use, distribution, and reproduction in any medium, provided the original work is properly cited. 


\section{INTRODUCTION}

The unique business environment forces organizations to utilize proficient systems for business improvement. Consequently, organizations must alter traditional marketing techniques with creativity and innovation to compete in the dynamic environment (Morris, Schindehutte, LaForge, 2002). The rapid-changing business environment of Sri Lanka, with exceptionally developing entrepreneurs of SMEs, was restrictive on growth and stability. They don't have the opportunity and assets for marketing. Yet, they invest significant energy conversing with customers, and afterward, they change them as loyal customers to their organizations (ADB, 2019). Even though they are essentially unaware of the marketing knowledge, women-owned SMEs in Sri Lanka, in general, need extensive energy and effort in marketing (Kawsalya, Dilani, Sunimalee, Athula, Anushka, \& Chopadithya 2014). This study reflects the EM dimensions and their significances for improving the marketing ability of women-owned SMEs.

The advances in information, knowledge, and innovation have assisted organizations with evolving goals for customers at brighter levels. Likewise, it has helped the customers by expanding information and becoming very educated about the decision and support needed and thus really requesting (Abeysekara, 2000). Organisations need to work in conditions as decreasing passage hindrances, growing rivalry, and rising investor pressure. Subsequently, they would need to turn out to be considerably more proactive, creative, and quick than any time in recent unsure economic situations. Even though around is a prerequisite between conventional marketing and EM (Hills, Hultman, \& Miles, 2008), a concession to the importance of entrepreneurial marketing is still to look into the brightness of the benefits of enterprise. Organizations utilize the possibility of EM diversely and often usually (Morrish, Schindehutte, \& LaForge, 2002). In the fundamental stages, it interfaces with the progressing effort of SMEs (Hill \&Wright, 2000) and to resource obliged organizations (Morris et al., 2002). While some thought about EM as the line of showing for newly established small firms, others seemed at EM from a conceptual viewpoint of publicising with the inventive expression (Miles \& Darroch, 2006). EM is pertinent to the relationship of overall size (Morrish, \& Gilmore, 2011).

Women-owned SMEs rely on an expressive and critical part in economic development by making occupations, advancing more remarkable financial growth, and using the practical limit of women (Brush, 1997). Expanding women's financial chances business can likewise support gender value, emphatically give to per capita expenses, and decrease poverty. Even though marketing has a significant part in firms' accomplishments, it is beyond vital for small to medium-sized entreprises (SMEs), which asset set up without undertaking methodologies (Ahmadi, \& O'Cass,2016). Numerous researchers guarantee that traditional marketing is not, at this point, satisfactory for the survival of SMEs. While pursuing new opportunities with confined assets, the businessperson should utilize organizing approaches despite such limits. It is fundamental for a business to incite entrepreneurial marketing strategies to achieve fruitful results and eventually profitability and development (Buddhadasa, 2003). 
Small and Medium Enterprises (SMEs) are of fundamental significance to business development as they create employment, period of pay, and poverty reduction. SMEs add to a significant contribution to the GDP of Sri Lanka. SMEs utilize the workforce and provide more excellent employment opportunities than big firms (Kawsalya, Dilani, Sunimalee, Athula, Anushka, \& Chopadithya 2014). Tragically, these SMEs face various business imperatives that ruin their development, including monetary and non-monetary requirements. They have a critical task to establish a businessaccommodating climate for SMEs, particularly for Women-owned SMEs (ibid.). Then again, with the difficulties of sector change and the growing general public, females' jobs will turn into a critical driving force of supported high economic development.

Nevertheless, female workforce investment in Sri Lanka isn't comparable to other improvement pointers of the country. Advancing women-owned business can be viewed as a successful method of drawing more females interested in the workforce and an engaging vocation for females (Adel, Mahrous \& Hammad 2020; Kawsalya Dilani Sunimalee Athula Anushka, Chopadithya, 2014). Even though marketing is a vital part of accomplishing firms' objectives, it primarily promotes small to mediumsized enterprises (SMEs). Numerous researches continue that traditional marketing systems are not, at this point, adequate for the perseverance of SMEs. While seeking new freedoms with restricted assets, the business visionary should utilize inventive methodologies despite such limitations (Seuwandhi Ranasinghe, 2011). Simultaneously, the marketing approaches used by businesspeople reflect this creative direction, which gently offers accomplishment to the women-owned SMEs.

The study question of 'what are the entrepreneurial marketing applications found by women-owned SMEs?' and contemplating the critical discoveries that reveal entrepreneurial marketing as reasonable to limited scope undertakings in literature. The expected consequence of this study is to fill the gap in the literature by giving a first composition that will interface the entrepreneurial marketing estimations with the introduction of women-owned SMEs in Sri Lanka. Furthermore, the results can be helpful for policymakers who think about the meaning of SMEs in the country's economy. As such, the study's eventual outcomes encourage the practice of EM dimensions in women-owned SMEs.

This study attempted to decide how much the existing marketing approaches show a blend of uniqueness to the EM and tried to perceive the instruments and applications women-owned SMEs looked for in changing EM in their enterprises. This study effort to commit to recognizing the space of marketing in women-owned SMEs as a rule and, all the more clearly, EM in women-owned SMEs. This study's novelty originated as EM has not been analyzed observationally from women-owned SMEs in Sri Lanka, which has gained little or no consideration. 


\section{RESEARCH OBJECTIVES}

- To find out Entrepreneurial marketing applications in women-owned SMEs in Sri Lanka.

- To categorize the Entrepreneurial marketing dimensions from the existing marketing practices of women-owned SMEs in Sri Lanka.

\section{LITERATURE REVIEW}

\subsection{Entrepreneurial Marketing}

Entrepreneurial marketing is a fascinating and evolving spectacle and uses traditional marketing approaches in another perspective of approaches. This idea combines two critical terms, entrepreneurship and marketing (Shaw, 2004). These market and innovative directions are essential for any organization to succeed, whether it is a small-scale or enormous firm (Andualem, 2003).

Fernandes, Ferreira, Lobo \& Raposo (2020) indicated that marketing is the way toward fulfilling customers' needs by recognizing and expecting customer needs and desires through a systematic assessment measure. The firm which creates market orientation exercises ought to supervise the unique climate and be a more responsive structure to oversee hyper-rivalry in the marketplace (Kara, Spillane, and DeShields, 2005). Market orientation is guided by marketing procedures as division, focusing on the suitable blends of fostering blends in a marketing data framework (Stokes, 2000).

Business venture looks for inventive plans to catch new open doors on the lookout, as a coordinated exertion to offer some benefit to the customers through a creative method of recognizing and satisfying the necessities of the customers (Adel, Mahrous \& Hammad, 2020). A firm with a driving direction seeks after development to meet the likely conditions of the customers, overseeing hazards, supporting novel thoughts, imagination, and being persuaded by high returns (Miller, 1983).

Entrepreneurial Marketing gives firms technical information and answers to fulfill customers' preferences and requirements (Gatignon \&Xuereb, 1997). Entrepreneurial Marketing is the positive advancement of business sectors where sellers search for better ways to make the expected worth. Morris (2002) comprehends that EM is the spontaneous, non-direct visionary advancing business visionary exercises. Likewise, the thought is battled by converging on the marketer as a business visionary who proactively searches for unique ways to boost needed customers and accumulate customer value (Morrish \& Jones, 2020). Therefore, entrepreneurial marketing is the proactive distinguishing proof and examination of chances for securing and holding valuable customers by leading ways to deal with the board, resource use, and value creation. (Morris, Schindehutte, and LaForge, 2002). 
The expression of EM consolidates two previously unique fields. It is utilized to portray the marketing cycles of firms seeking favourable circumstances in doubtful market conditions regularly under compelled asset conditions (Adel, Mahrous \& Hammad, 2020). The term depicts a scope of activities and reactions SMEs can utilize (Becherer, Haynes, and Helms, 2008). Adel, Mahrous, Hammad (2020) seemed to promote businesspeople versus administrators with minimal innovative control and affirmed huge contrasts in marketing under helplessness. They discovered that administrators without entrepreneurs depended on proactive marketing strategies while other businesspeople implemented non-predictive rationale techniques.

EM has been recommended best when natural change is extraordinary and restricted assets (Janet \& Ngugi, 2014). Martin's (2009) research likewise discovered qualifications of innovative marketing applicable to small firms. She contrasted conventional corporate marketing with entrepreneurial marketing and approved a system for investigating marketing rehearses explicit to business visionaries, featuring the distinctions in demonstrating studies by businesspeople.

Entrepreneurial marketing has set out freedom for the turn of events of a few study streams, which came about in different perspectives and meanings of EM ideas. One focal study stream was introduced by considering analyzing SME promotion. Because small organizations are not small-scale interpretations of an enormous organization (Story, 1989), there was a need to finding an EM model that small organizations can apply.

\subsection{Women and SMEs}

Women's activist philosophy (Fischer, Bielinsky, Nitzgen, Däubener, \& Hadding, 1993) proposes that SMEs' ownerships show more unsuitable execution since women are victimised or due to other efficient components deny women of fundamental assets. Via contrast, the social women's activist theory (Fischer et al., 1993) recommends that people are naturally extraordinary fundamentally. These distinctions don't suggest that women will be less compelling in business than men, yet just that they may receive various methodologies which may, or may not, be similarly pretty much as successful as the systems embraced. Visionaries of Women's business play a fundamental role in supporting governments by contributing significantly in different horticultural nations. SME improvement and advancement help prepare enterprising activity and self-governance and, at the equivalent time, strengthen multicultural and social liberation measures.

Anna et al. (1999) recommended any systematic contrasts in SME execution by sex because woman business proprietorship is moved basically in marketing and enterprises, which are relatively more modest regarding work and income than high-level technology construction and assembling. Likewise, Rosa, Carter, and Hamilton (1996) contend that, at minimum, some of the sexual orientation distinctions 
in business execution may be identified with industry discrepancies because women will, in general, begin organizations in areas that have low returns. Likewise, Brush (1997) note that ventures requiring minimal capital will probably have the most elevated conclusion rates. When a lot of money is in question, the proprietors are expected to make a more intensive examination of the possibilities for the new responsibility. Given the relatively lower obstacle (regarding capital necessities) for building up, adventures could be required to have more excellent closure rates. Further, they commonly have a more significant dependence on their author and may well stop when that individual resigns or chooses to seek after an additional action (Watson and Everett, 1993).

For the most part, EM is a new area of study, which has maneuvered into the thought of different scholastics. Nevertheless, even though there are other results in writing search, a set number of articles have mulled over the effect of EM on SME execution and improvement. Business is an excellent fit for eliminating every offense related to financial development, social deviations, and other barriers. Numerous nations of the world are effectively looking for available resources to advance business ventures. The meaning of SMEs reflects the need to give business, redesign monetary turn of events, and make additional capital for tremendous extension undertakings in less created countries (Kraus, Harms, \& Fink, 2010). Muma (2002) battles that SMEs add to themselves upheld improvement and progression of nations. Of late, factors like privatization, specialization, corporate revamping, and downsizing have additionally supported such endeavours (Lehman, Fillis, \& Miles, 2014).). Besides, SMEs' advancement speeds up accomplishing more extensive monetary and financial destinations, remembering neediness lightening for agricultural nations.

Markets and predictions made by expanded globalization are likewise specifically useful for independent enterprises (Garnick, 2006), and then some and all the smaller firms are going worldwide (Delaney, 2004). Most likely, continually expanding worldwide competition presents difficulties to organizations of all shapes and sizes. Their decision to take work abroad can be hazardous, particularly for more modest organizations that need assets to reflect upon if a specific industry fails to work out (Martin, 2009). We can't deny that more independent companies exploit the re-appropriating pattern (Mort, Weerawardena, \& Liesch, 2012). Many small-scale businesses open doors for home-based organizations to market their products abroad, making what some would call a shared benefit situation (Strauss, 2004). At this point, women could be the significant beneficiaries who make up most of the limited-scale business visionaries, particularly in non-industrial nations (Blackman, 2000).

Many agricultural nations underestimate women, but increasing women's existence infers a significant effect on their families' realities. Additionally, on account of SME factors like age, sexual orientation, schooling and preparing, family foundation, nationality, religion, network enrollment, what's more, inspiration, notwithstanding other severe and underlying elements, plays a significant role in influencing business visionary conduct and dynamic (Porter, 1980). Women's business visionaries have all the 
allocates of being prompted to go into their own business to work for themselves, to land position fulfilment, for monetary autonomy, or for a chance to be more imaginative (Kandasaami and Tibbits, 1993).

Sri Lanka was confronting 30 years of very much reported ethnic emergency, which brought about a common conflict. After the finish of the 30-year war, Sri Lanka is on the way to rejuvenating its economy. In this undertaking, the SME sector has assumed a pivotal part in adding to the country's financial turn of events (World Bank Group, 2011). SMEs are found in all areas of the economy in Sri Lanka. Those areas are industry, exchange, and enterprises (Gunawardana, 2016). In Sri Lanka, it is assessed that over $90 \%$ of organizations fall under the SME Sector, which contributes 52\% to the GDP and gives $45 \%$ of complete work in the country (Ministry of Industry and Commerce, 2016). Also, about 2.25 million individuals in Sri Lanka are utilized by SMEs (Gunawardana, 2016). The Census and Statistics Department delivered its first monetary registration report in 2013/2014 on the business, exchange, and enterprises area, affirming that the quantity of foundations in the SME area is 1.017 million (Gunawardana, 2020).

The women's business is getting progressively famous across the globe. The interest of women is one of the significant patrons in financial development. Their commitment to yield and esteem expansion is substantial, independent of their inclusion in small-scale endeavors or the recognized areas. Women's business venture isn't as essential for their monetary endurance besides reinforcing the social framework. Cultivating women's business improvement is in this manner critical for financial development and improvement.

\subsection{Entrepreneurial Marketing Dimensions}

Previous research has perceived several characteristics of EM behaviours similar to interest to development (Whalen et al., 2016), determined risk-taking (Hills \& Hultman, 2013), flexible approaches to business sectors (Shaw, 2004). On account of the diverse number of characteristics given by various researchers' number of discussions have textured in the written works as to the idea of the build of EM, its dimensionally (Hills \& Hultman, 2006), the association of the dimensions (Kilenthog, Hultman \& Hills, 2016), and the idea of the measurements (Hills \& Hultman, 2006). Kilenthong et al. (2015) proposed Proactiveness, risk-taking, imaginativeness, opportunity focus, asset utilizing, customer force, and value creation as six dimensions of EM. Previous work identified seven dimensions: proactiveness, innovativeness, customer intensity resource leveraging risk-taking, opportunity focus, and value creation (Morris et al.,2002) of EM.

Proactiveness is a reaction to favourable circumstances and gives an organizational capacity to anticipate the progressions or customer needs and respond to them quickly (Lumpkin \&Dess, 2001). 
Determining taking risk is the organization's capacity to utilize persistent activities to decrease the danger of chance search (Becherer et al., 2012). Risk-taking implies a willingness to pursue prospects that have a reasonable possibility of creating misfortunes or includes a preparation to engage in opportunities that have a sensible option of delivering troubles or substantial implementation fault (Nwankwo, \& Kanyangale, 2020). Innovation is characterized as the company's capacity to maintain a progression of groundbreaking thoughts that can be deciphered into new products, enterprises $\mathrm{s}$, innovations, or markets (Nikfarjam \& Zarifi, 2015). Development may assist firms with moving past a promising circumstance centre that represents unseen marketplaces that are wellsprings of supportable benefit potential. Today's prospective acknowledgment has a significant job in business venture assumption and has a vital drive-in business research (Janet \& Ngugi, 2014). Commitment to favourable circumstances and opportunity recognizable proof abilities are elements that separate EM from traditional marketing (Hills et al., 2008). The firm's capacity is found to determine the event that decides achievement (Becherer, Haynes, and Helms, 2008). Asset utilizing is the firm's capacity to access assets to accomplish extra with fewer (Becherer et al., 2012). As per Morrish et al. (2002), enterprising marketers can use assets from various perspectives like perceiving assets to expand their worth, utilizing certain assets to discover different assets, and growing assets considerably more than others have done before. Client force is a vital component of EM and the focal component of market situating development (Kohli \& Jaworski, 1990). The value idea is portrayed as the marketers' errand to discover the new wellspring of customer value and make unique examples of sources to create value (Morris et al., 2002).

\section{RESEARCH METHODOLOGY}

This study has undertaken qualitative research methods and explorative research design since the concept of women-owned SMEs is a relatively new and intact issue. Data have been gathered through in-depth interviews with 49 female-headed SMEs in five districts of Sri Lanka. The theme of this study is to recognize the respondent's experience through a subjective view of the research event. Furthermore, understanding the experience of individuals and groups from women-headed SMEs is central to this study. Also, along with the contributors, a researcher is a part of this study. So, research cannot remove this. Also, in this study, a small number of respondents were approached individually through interviews, and a qualitative approach was adopted to gain a deeper understanding of the research study (Martin, 2009). This study uses an inductive approach as this study was organized to explore the seven dimensions of EM in women-owned SMEs.

To conduct this study, the researcher decided that qualitative data collection is more suitable since qualitative research is more likely to deliver necessary contextualization and clarity to research questions and ideas than hypothesize and test variables. Qualitative research takes place in a physical setting, which allows the researcher to produce many details from more extensive participation in real 
experiences (Creswell, 2003). This study's qualitative data collection method was better to understand the entrepreneurial marketing elements in women-owned SMEs. Women-owned enterprises are vulnerable as they were sternly overstated by the civil war that was ended in 2009 in Sri Lanka.

The purposive sampling method involves selecting specific units or cases based on the particular objective rather than selecting at random (Creswell, Plano Clark, Gutmann, \& Hanson,2003). According to Patton (2002), establishing the purposive sampling technique in a qualitative study delivers more information on a context with a small number of respondents who are chosen purposely. In the purposive sampling technique, the sample selection is made according to the researchers' ability and the opinion that individuals are suitable for the research. Since it is impossible to survey the widely dispersed population of this study, who are women owners of SMEs in Sri Lanka, the researcher has selected 49 women-owned SMEs in five districts (Jaffna, Mullaithivu, Mannar, Vavuniya, Killinochchi) of Sri Lanka with different demographic characteristics. The researcher assessed that the selected respondents had specific knowledge that could answer the research question of this study.

\section{DATA ANALYSIS}

Both secondary and primary data were analyzed depending on the subjects to examine the substance from respondents' experiences. The study utilized both primary and secondary data. The critical data source was Key Informant Interviews (KIIs). Secondary information resources were the industries annual survey (Department of Census and Statistics), world bank Enterprise Surveys, etc. Data collected in this study were analyzed through detailed analysis utilised in subjective explores. In the fundamental stage of this study, the personal information collected from the in-depth informants' interviews was translated from sound recorders to a comprised page. The researcher dissected the respondents' assertions interpretatively, considering their current marketing approaches and applications in the subsequent step. Hence, how much these methodologies show association or dissimilarity to the EM approach was resolved. The certifications chosen from the talk with records and assessments to investigate discoveries are presented by employing thematic analysis for classifying the seven EM's components.

\section{RESULTS AND DISCUSSIONS}

\subsection{Proactiveness}

The discussions show that female-owned SMEs of Sri Lanka act proactively. They explained that they attempted to understand the climate, customers, and competitors at familiarizing the business. They tried to pursue customers' responses after their marketing activities. Later, they aimed in on what they did and continued after the best approach to do matters that ended up being effective. The Sri Lankan women-owned SMEs propose new products to the clients simultaneously, fulfilling their requirements 
or enterprise prerequisites. Some take guidance from the relevant provincial firms that work with them for imaginative gear and redesigns. By preparing programmes and the aides, they better investigate groundbreaking thoughts occasionally and succeed in their ventures.

Driving and organizing the market regarding making new products and receiving and offering innovations carry enthusiasm to showcase the tactics of organizations. In this study, the accompanying receptive completed queries were posted to women owners of SMEs to quantify the proactive component of EM. Have you characterized yourself as a "creator" regarding new item development, invention implementation, and offering unique products to the market? Assuming this is the case, could you kindly clarify your spearheading job and exercises in the market with a solid model? Could you, if it's not too much trouble, share with us a particular case that discloses how you figure out how to assess the changes in the business centre earlier than your rivals with a proactive approach? This study found that women-owned SMEs referenced that they attempt to keep a unique way to be a pioneer in offering products and enterprises. In this individual situation, the exercises are carried out proactively by the women-owned SMEs.

Women owners flourish on customer service, knowledge, and relations and interact with customers continually. They realised that owning prosperity of material can be very influential in the health and growth of their SMEs. Owners engage with their marketing team frequently through meetings, surveys, and retreats. Through this process, the team member relationship and help better serve their customers. For example, a women owner expressed that:

"We expect the challenges happen future we plan today, my teamwork with this ability and we observe the market, and we do substitute and intelligent fast of expected actions. ... to provide the customer service, we make the first move, while the customer makes a move in responsive customer service."

Another respondent mentioned that:

We offer something new to the customers before the competitors do. We do not wait for things to happen. We work in advance; my competitors follow me.

\subsection{Risk-taking}

Women-owned SMEs in Sri Lanka expressed that they were occupied with risky exercises that, in any event, starting their business. Also, they characterize themselves as individuals, face challenges, and are creative in any dangerous situation. Women-owned SMEs demonstrate that they take an interest in risk projection or estimate. They have understood the significance of deciding risk yet affirmed that nobody accomplished for them. They asked, 'how should it be finished? Who should be finished? From the computation of risk, what should we do?'. Woman-owned SMEs in Sri Lanka anticipate risk-taking 
because of the ecological uncertainly, a work by changing activities as indicated by the quickly changing business climate. Women owners felt that they should take risks since which is serious to success. Without them, they said they would never create innovative companies or products, never find new chances or climb to new levels of success. They understand that external work, risks are what help them feel brave and alive.

Respondents believed that considering risk-taking and organizing in finding proactive developments are significant characteristics of businesses. This study posed open-ended questions to respondents to determine the risk-taking element of EM: What is risk adopting a strategy you undertake in your business? Most of the respondents referenced that they faced significant challenges in risk-taking in their speculation choices. In those situations, they acted innovatively and unsurprising. For example, a respondent attested the accompanying articulation concerning risk adopting strategy.

"I don't face such a lot of challenge for the space that I figured I would not acquire to such an extent. I feel that a financial supporter can face a challenge with their collaborator by limiting the risk."

Another respondent expressed that:

"We do expect a risk. I can accept any risk when I remember it as a type of opportunity regardless of whether there is an opportunity of committing an error toward the end. There is an intense disposition towards risk-taking in my firm"

"We do marketing that involves risk to attain a goal. Taking risks is a chance to learn. Without risk, we will not experience failure. Therefore, we will not learn from our mistakes. In addition, taking risks teaches us essential skills such as calculating contingencies and strategic thinking and planning."

\subsection{Innovativeness}

The women-owned SMEs realized that creativity in Sri Lanka by delivering new products, enterprises in the market might force their organizations. Women-owned SMEs work through online media to give a creative approach for being in contact with clients. Even though SMEs in Sri Lanka embrace creativity to various degrees, practically everyone asserts that they attempt innovative marketing practices instead of research and development. The craft-making enterprises show themselves as makers of new needs of the customers. They investigated imaginative thought structure nearby specialists just as unfamiliar trained professionals, and they talk about their noticing the market for creative thinking.

The following questions were asked to collect data from the respondents (Tse, 2004). How do you oversee and react to the current fads in your enterprise if it's not too much trouble? Do you show constant 
exertion to improve your products and organizations? Would you be able to give us an illustration of such developments if it's not too much trouble? What is your business-arranged for the forthcoming three- or five-year time frame? Which things, enterprises, or creations do you change to make the upper hand? How continuous? If you don't mind, kindly give us a model about it? Would you be able to characterize the significant competition elements in the same business area if it's not too much trouble? What sort of procedures do you seek to battle with the competition?

Members have expressed that all SMEs in this study have made developments inside the most recent three months or one year. Hence, they routinely visit the industry exhibitions in the province and at the national level to request advancements or transformations. For example, a respondent expressed that:

"We are continually saying facts by going to national fairs. Plus, as the owners of the enterprise, we oblige in other enterprises and notice their practices. We at that Point apply those perceptions to our firms in the structure of variations instead of impersonation."

Moreover, customer visits pay close consideration regarding sales and their potential commitments to the firms' enterprises. For example, a respondent expressed that:

"We are continually following advancements, particularly automated customer management system. Changes in products and enterprises are being made as per customer criticism."

Another respondent (food producer) said that:

We always pay attention to customer complaints and their feedback; we change the design according to their ideas. We innovatively reach the now we change the delivery methods ... customers get as very quick to meet their needs.

\subsection{Opportunity Focus}

Most of the women-owned SMEs showed a longing to extend their business. They showed a tendency to grow both in new products and market are driven by the market openings. They want to expand to most urban communities and towns in Sri Lanka while others accentuate opening new nearby places. They are supposed to give new products, fresh selling methods, and advancing products, thinking they now have no marketing supplies.

They expressed those ventures with an EM point of view have better mindfulness in separating and assessing open doors following their present procedures and situation in the commercial centre. Such undertakings go past their current methodologies and look for new freedoms. In this study, the accompanying open-ended queries were posed to respondents to quantify the chance-building element of EM: How does your firm choose the chances? What sort of exercises does your firm seek to recognize 
openings in the commercial centre? The respondents expressed that they all put forth an attempt to distinguish spaces in the commercial centre with the accompanying assertions:

\footnotetext{
"We put together friendly visits, (for example, visiting area fairs and making projections regarding sectoral advancements), break down the market and watch our rivals' notices intently, visit uncommon idea fairs (Wednesday market, free demonstration, preparation with customer participation and so on), investigate into markets like SME sector for forthcoming ventures and search for new ideas and improvable components to get the ideal advantage of building plan with the most proficient and powerful use of the human resource."
}

Besides, the interviewees gave the accompanying models concerning how they exploited the openings in the firms, women expressed:

"We are attempting to make a more creative and social enterprise idea, that claims to specialists, making a market-arranged supply chain, drawing the consideration of the market with a cutting edge and profoundly mechanical plan, having a craftsman work on an inside plan, and making another climate with unique compositions and models."

Along these lines, another respondent expressed that:

"There are just a single micro-enterprise and some other small-scale enterprises around here. There isn't any form in furnishing its clients' satisfaction in rural areas with high-value creation. Our lodging was established to fill this gap. I believe that we saw and correctly assessed this opportunity."

\subsection{Resources Leveraging}

Women concur that it is critical to put resources into what believes right. It brings achievement and is a rationale. Their decisions appear to be instinctual. Addressed to the proficiency of their underlying interests in their marketing exercises, they preached that the outcomes were acceptable, some of the time far superior to anticipated. However, business visionaries wish to utilize their assets improved, but they have no clue how to do it. Purchases used in entrepreneurial marketing rely upon the businessperson. Five of the respondents have made involved with stores to sell their products. They discovered it as a decent method to extend the business. All of them are associated with dependable providers who bring variety and assist them with getting assets identified with marketing.

Regarding asset utilizing, they highlighted the need to use the favorable outside circumstances and the ones in assets inside, they undertakings with the EM go-to versatile methodologies with a more modest spending plan. The following open-ended questions were asked to the respondents. Is the principal determinant of distinguishing and misusing a chance restricted to your existing investments, or, in 
general, do you move towards outside financing or re-appropriating not to pass up on the event? Predictable with the literature, respondents referenced that they generally utilized restricted assets. For example, one woman expressed that:

"Contingent upon the circumstance, we both use embracing and re-appropriating. We make a choice thinking about our present circumstance and potential advantages of this choice."

Another respondent declared that:

"We utilize elective external assets, for example, getting a credit (depending on financial sponsor's decision) or we share the resources which are provided by the industrial people given as shared resource (packaging machines, drying equipment, vending tools, for instance as costly equipment and tools purchased and supplied as shared resources"

Regarding asset utilizing, interviewees expressed that financial sponsors' choices represented a massive cutoff, and ventures with a lower spending plan focused on appropriate changes were supposed. Respondents communicated that their spending on staff's personal development immediately impacted their enterprise's quality.

\subsection{Customer Intensity}

Sri Lankan women-owned business visionaries put efforts on close-to-home organizations with customers and depend strongly on verbal interaction. They rely on the customer's assessment and work to make an unquestionable fulfilment for the clients. Interviews demonstrate that women-owned SMEs in Sri Lanka are customer accumulated and put resources into building individual relationships. The majority of the SMEs affirmed to tune in to customers and realize their requirements. SMEs in Sri Lanka are motivated by making and supporting a constructive relationship with their customers. Value Creation as previously examined; the interviewees respected the customers as the primary impetus for their business. They showed preparation to satisfy customer needs and are attempting to fulfil them. Informal marketing is the sign for their exercises, pondering those numerous new customers are made through their companions and family members. Appropriately, "value creation" assumes a part of the business visionaries in Sri Lanka.

A viewpoint on entrepreneurial marketing with attention to customer needs shows that they look for opportunities proactively to increase the customer force. A unique point in this understanding is that an undertaking with groundbreaking exercises can create specific experiences through an arrangement that will serve future customers' dormant requests for non-existing products. This study posed to measure customer intensity measurement of EM (Kocak, 2004): Do you imagine that your missions' necessities and needs are of first concern for your enterprise? Is your enterprise ready to decide the progressions 
effectively in journeys' assumptions? How might you profit from such information in your sales? Does your enterprise measure consumer loyalty? How and how regular? Does your enterprise figure out how to utilize these consumer loyalties? Results proficiently in improving your business measures. Do you keep up your correspondence with visitors regardless of whether they leave your enterprise? Could you kindly give us a couple of models concerning the exercises your enterprise has received for this reason?

The respondents clarified that they arranged and built up their customer centre with a proactive point of view. To accumulate information for customer force, utilize surveys, CRM framework yields, interviews, customer requests on the web locales, patterns at the food industry fairs, and advancements made by contenders. Because of these sources of information, women-owned SMEs do customer-locate performances and attempt to generate and offer new enterprises and products, recover existing ones, and configuration new staff instructional meetings. For example, a respondent in food manufacturing small enterprises expressed that:

"Customer requests and needs are of crucial significance for us. We follow these requests and needs through the two reviews and communication. Customer thoughts empower us to understand the developments."

Another respondent affirmed that:

"Employees and customer relations are continually receiving criticism from our customers in each contact point with customers, for example, order placement, delivery, and so on. Plus, customer overviews are used for this reason."

Respondents likewise demonstrated that they continually estimated consumer loyalty with polls, meetings, and information gathered utilizing the web. Under the light of client fulfilment estimates, snack producers offer curiosities, for example, quick order placements and delivery measures and making special orders for special occasions plans as per customer needs. The consumer loyalty input acquired by the food delivery is additionally utilized in choice-making for new ventures. For example, a respondent beauty parlor owner communicated that:

"We measure consumer loyalty through reviews. Our consumer loyalty proportion is entirely satisfactory, which is more prominent than our expectations. We think this is because of the different value proposition."

From an informant's point of view on EM, it identified that that individual interaction and correspondence networks on small and medium enterprises describing marketing inclinations are critical. Along these lines, respondents demonstrate that they connected with clients continually and utilized different techniques to maintain their correspondence network cutting-edge and solid. Among their designs are as per the following: 
"sending e-mails on special occasions (wishes for their birthdays), making phone calls at specific intervals (calling the customers when they do not visit for buying for a long time, accompanying the customer to his/her following levels of need after he/she leaves the enterprise (dinner -door delivery, cleaning assistants, cook at home by assistants."

\title{
6.7. Value Creation
}

Another significant part of EM is the value creation process for clients. SME owners pointed out the requirement for chances to shape a various level structure portrayed by originality, risk-taking, and proactiveness to make, pass on, and offer an incentive for customers. They worked on two primary methods of significant value creation. In the first place, it is to increment the advantages of substantial value contributions for clients. Second, it diminishes the expenses of procurement, use, and dispersion of the item and enterprises offered by the venture to the customers. This study posed open-ended inquiries to respondents to quantify the value creation measurement of EM (Kocak, 2004): What do you do overall to make an incentive for your current or potential new clients? Do you help different firms in your area to create an incentive for Your customers? Could you kindly give us a solid model for this? Do you gauge the apparent worth of your customers regarding your enterprise?

Appropriately, interviewees expressed that:

\begin{abstract}
"We are planning to offer some instant nutritional food for following our client's requirements following services at enterprises." "We are attempting to make respect with occasions for our client after they leave the shops. For example, we plan surprises, welcoming a famous entertainer to invest power with our expeditions.
\end{abstract}

Another respondent mentioned that:
"We are helping out different enterprises to address our customers' issues That our enterprise can't react. For example, we don't have a special design as the customized product in our jewelry design list, so we are guiding our clients to another women-owned business that has many customized designs." "We offer enterprises s for our clients that empower them to proceed with their day-by- day trends." "We develop and offer natural products of the soil and make nutritional cereals from our grains."

Respondents also specified that they estimated customers' view of the qualities made and that such measures, in any case, accompany certain restrictions. SMEs think about the assessments of repeat missions and first-time customers going to the enterprise, which provide refreshments, instant food as nutritional and traditional food to customers. They expressed that limited time exercises in marketing activities that broaden the customer base depend strongly on verbal exchange Interaction and customer plans. 


\section{CONCLUSION}

This study examines the use of seven EM measurements: proactiveness, customer intensity risk-taking, opportunity focus innovativeness, resource leveraging, and value creation in women-owned SMEs. Interview results showed that the seven EM elements were disguised and applied viably to promote SMEs' promising outcomes. Women owners have a restricted understanding regarding marketing applications, yet one part was combined for all, the attention on customers' needs. They work to make customers their king, who are satisfied with the product they push ahead of the organizations for progress.

The proactive behavior of the women-owned SMEs in Sri Lanka explains the self-initiated behavior that solves a problem before it has happened. They involve acting in advance of an upcoming condition, somewhat than countering. They constantly observe future activities, schemes, and actions and forestall needs, difficulties, and conceivable outcomes in advance. For example, suppose they are launching a new product in a different segment. In that case, they go beyond actually understanding the market, receiving customer feedback point of sales feedback collection, and observing the product life cycle of the rivals to compete via new product features. They experience from being proactive involves doing and rational in advance of expected actions. To provide proactive customer service, they make the first passage while the customer moves in responsive customer service.

A risk-taking dimension that women entrepreneurs have allows and inspires novelty, which can be a significant product/service discriminator. They perceive that the failed risks aren't continuously bad. Sometimes, they deliver the most appreciated business instructions their employees can learn. They further assumed that failure aids outline the future business strategies and can ultimately lead to business development.

Women owners encourage fruitful new ideas as being able to advance their procedures, carry new and better products and services to market, increase their competence and, most prominently, progress its success. They establish the culture of creating new business ideas to produce profit, support their public, and achieve company goals. They maintain them as Groundbreaking entrepreneurs to grow business models to classify to meet customers' needs through regular market study and improve their competitiveness in the market.

Women-owned SMEs can encourage their business quicker, hire more people, and introduce novelty that could help fill essential gaps in the market while boosting efficiency in the economy. They help SMEs expose, grow and use those chances that make success. They direct to where consumer ways, wants, favorites and reliabilities intersect with their business ability to fill those vacuums. 
This study identified that these women systematically measure their present business properties, classify the need for supplementary resources, or create new resources in public and state systems to address recognized wants. For this purpose, they get help from the expertise in the higher education institution and industrial people. Selected SMEs connect with their customers to build relationships, identify their expectations, and regularly collect customer information as to their feedback on products and services. They receive ideas to form their customers and express appreciation to their customers. SMEs owned by women are concerned about value creation as a primary strategic goal of their businesses. They set themselves apart from their rivalry, safeguard lasting clienteles, and transports distinct meaning to their brands and products. They realized that their unique offering is just another product without creating value in the target market's eyes. They convey their value propositions at all the customer touchpoints in the enterprises. Among Sri Lankan SMEs, entrepreneurial marketing is defined by knowledge. They adjust their product and service models via data gathering through individual contacts instead of purposeful market insight. They work through intuitive marketing strategies, building firms with existing clients, and verbal exchange to discover new ones.

This study addressed how entrepreneurial marketing dimensions are applied in women-owned SMEs in Sri Lanka. This study is limited to the number of samples taken from a particular district. Future research can extend the findings with the large sample size from multiple cultural places and study the entrepreneurial marketing dimensions in the SMEs operating in different communities of Sri Lanka with cultural differences.

\section{REFERENCES}

Ahmadi, H. and O'Cass, A. (2016), "The role of entrepreneurial marketing in new technology ventures first product commercialization," Journal of Strategic Marketing. Routledge, Vol. 24 No. 1, pp. 47-60.

Abeysekara, W. I. M. (2000). Some common characteristics of successful Sri Lankan female entrepreneurs (Unpublished Master's thesis). Postgraduate Institute of Management, University of Sri Jayewardenepura, Colombo

Amarasiri, J. (2002). An exploratory study on a group of selected business women in Sri Lanka. Paper presented at the Eighth National Convention on Women's Studies, Colombo: Centre for Women's Research.

Buddhadasa, S. (2003). Challenges, issues, and growth orientation of Sri Lankan entrepreneurship. Economic Review, 29 (1 - 3), 2 - 6.

Anna, A. L., G. N. Chandler, E. Jansen and N. P. Mero. (1999). "Women Business Owners in Traditional and Non-Traditional Industries." Journal of Business Venturing. 15(3): 279303.

Adel, H. M., Mahrous, A. A., \& Hammad, R. (2020). Entrepreneurial marketing strategy, institutional environment, and business performance of SMEs in Egypt. Journal of Entrepreneurship in Emerging Economies.

Andualem, T. (2003), "Entrepreneurship and small business development in Ethiopia," paper presented at Symposium on Human Resources Development, the 5th of October 1995, 
Adel, H. M., Mahrous, A. A., \& Hammad, R. (2020). Entrepreneurial marketing strategy, institutional environment, and business performance of SMEs in Egypt. Journal of Entrepreneurship in Emerging Economies.

Brush, C.G. (1997), "Women-owned businesses obstacle and opportunities," Journal of Development Entrepreneurship, Vol. 2 No. 1, pp. 1-24.

Becherer, R. C., Haynes, P. J., \& Helms, M. M. (2008). An exploratory investigation of entrepreneurial marketing in SMEs: The influence of the owner/operator. Journal of Business and Entrepreneurship, 20(2), 44.

Blackman, R. L., \& Eastop, V. F. (2000). Aphids on the world's crops: an identification and information guide (No. Ed. 2). John Wiley \& Sons Ltd.

Becherer, R.C., Helms, M.M., \& McDonald, J.P. (2012). The effect of entrepreneurial marketing on outcome goals in SMEs. New England Journal of Entrepreneurship, 15(1/2), 1-7.

Becherer, R. C., Haynes, P. J., \& Helms, M. M. (2008). An exploratory investigation of entrepreneurial marketing in SMEs: The influence of the owner/operator. Journal of Business and Entrepreneurship, 20(2), 44.

Creswell, J. W., \& Creswell, J. (2003). Research design (pp. 155-179). Thousand Oaks, CA: Sage publications.

Crick, J. M., Karami, M., \& Crick, D. (2021). The impact of the interaction between entrepreneurial marketing orientation and coopetition on business performance. International Journal of Entrepreneurial Behavior \& Research.

Christensen, C.M., 1997. "The Innovator's Dilemma: When New Technologies Cause Great Firms to Fail", Harvard Business School Press, Boston.

Delaney, L. (2004), "Small businesses are going global," available at: www.smallbiztrends.com/2004/09/smallbusinesses-are-going-global.html (accessed the 5th of February 2007).

Davis, D., M., Morris and J., Allen, 1991. "Perceived environmental turbulence and its effect on selected entrepreneurship, marketing, and organizational characteristics in industrial firms", Journal of Academy of Marketing Science 19, No. 1, pp. 43-51.

Fischer, H. G., Bielinsky, A. K., Nitzgen, B., Däubener, W., \& Hadding, U. (1993). The functional dichotomy of mouse microglia developed in vitro: differential effects of macrophage and granulocyte/macrophage colonystimulating factor on cytokine secretion and antitoxoplasmic activity. Journal of neuroimmunology, 45(1-2), 193-201.

Fernandes, C. I., Ferreira, J. J., Lobo, C. A., \& Raposo, M. (2020). The impact of market orientation on the internationalization of SMEs. Review of International Business and Strategy.

Gatignon, Hubert and Jean-Marc Xuereb (1997), "Strategic Orientation of the Firm and New Product Performance," Journal of Marketing Research, 34 (February), 77-90.

Garnick, R. (2006), "Globalization's gloomy guess must adapt. Business week", available at: www. businessweek.com/technology/content/mar2006/tc20060321_296404.htm(c20063839)

Gunawardana, S. J. (2016). 'To finish, we must finish': Everyday practices of depletion in Sri Lankan exportprocessing zones. Globalizations, 13(6), 861-875.

Gunawardana, K. D. (2020). E-commerce in small and medium enterprises in Sri Lanka. In Start-Ups and SMEs: Concepts, Methodologies, Tools, and Applications (pp. 634-649). IGI Global.

Hills, G. E., Hultman, C. M., \& Miles, M. P. (2008). The evolution and development of entrepreneurial marketing. Journal of Small Business Management, 46(1), 99-112. 
Hill, J., \& Wright, L. T. (2000). Defining the scope of entrepreneurial marketing: a qualitative approach. Journal of Enterprising Culture, 8(01), 23-46.

Hills, G. E., \&Hultman, C. (2013). Entrepreneurial Marketing: Conceptual and Empirical Research Opportunities. Entrepreneurship Research Journal.

Hills, G. E., \& Hultman, C. M. (2006). Entrepreneurial marketing. She was cited in: Lagrosen, S. and Svensson, G.(eds) Marketing-Broadening the Horizons, Denmark: University of Studentlitteratur.

Janet, M., \& Ngugi, K. (2014). Influence of entrepreneurial marketing on the growth of SMEs in Kiambu TownCBD, Kenya. European Journal of Business Management, 1(11), 361-377.

Jogaratnam, G. and E.C.Y., Tse, 2004. "The entrepreneurial approach to hotel operation: evidence from the AsiaPacific hotel industry", Cornell Hotel and Restaurant Administration

Quarterly 45, No. 3, pp. 248-259.Kraus, S., Harms, R. And Fink, M. (2010), Entrepreneurial Marketing: Moving beyond Marketing in New Ventures, International Journal of Entrepreneurship and Innovation Management, 11(1), pp.19-34.

Kraus, S., Harms, R., \& Fink, M. (2010). Entrepreneurial marketing: moving beyond marketing in new ventures. International Journal of Entrepreneurship and Innovation Management, 11(1), 19-34.

Kawsalya, A., Dilani, H., Sunimalee, M., Athula, S., Anushka, W., Chopadithya, E.. (2014.). Female Entrepreneurship and the role of business development services in promoting Small Medium entrepreneurs in Sri Lanka. A joint publication by the institute of policy studies of Sri Lanka and Oxfam international Sri Lanka, May 2014.

Kara, A., Spillane, J.E. \& DeShields, O.W. (2005). The Effect of a Market Orientation on Business Performance; A Study of Small-Sized Service Retailers Using MARKOR Scale, Journal of Small Business Management, 43(2), 105-118.

Kandasaami, T., \& Tibbits, G. E. (1993). An empirical investigation of women small business owners. Fostering small enterprise growth. In Joint SEAANZ and IIE National Small Enterprise

Kilenthong, P., Hills, G. E., \& Hultman, C. M. (2015). An empirical investigation of entrepreneurial marketing dimensions. Journal of International Marketing Strategy, 3(1), 1-18.

Kohli, A. K., \& Jaworski, B. J. (1990). Market orientation: the construct, research propositions, and managerial implications. Journal of Marketing, 54(2), 1-18.

Knight, G. A. (1997). Cross-cultural reliability and validity of a scale to measure firm entrepreneurial orientation. Journal of Business Venturing, 12(3), 213-225.

Kocak, A., 2004. "Developing and validating a scale for entrepreneurial marketing." UIC/AMA Research Symposium on the Interface of Marketing and Entrepreneurship. Nice. France. 30 June-2 July 2004

Kraus, M. W., Piff, P. K., \& Keltner, D. (2009). Social class, sense of control, and social explanation. Journal of Personality and Social Psychology, 97(6), 992.

Kotler, P. (2003). Marketing insights from A to Z: 80 concepts every manager needs to know. John Wiley \& Sons.

Lehman, K., Fillis, I. R., \& Miles, M. (2014). The art of entrepreneurial market creation. Journal of Research in Marketing and Entrepreneurship.

Lumpkin GT and Dess G.G. (1996) Clarifying the entrepreneurial orientation construct and linking it to performance. Academy of Management Review 21(1): 135-172.Lam \&Harker, 2015 
Martin, D.M., 2009. "The entrepreneurial marketing mix," Qualitative Market Research International Journal 12, No. 4, pp. 391-403.

Morrish, M.H., Schindehutte, M.,\&LaForge, R.W.(2002).Entrepreneurial Marketing: A construct for integrating emerging entrepreneurship and marketing perspectives. Journal of Marketing Theory and Practice, 10(4),119.

Morris, M. H., Schindehutte, M., \& LaForge, R. W. (2002). Entrepreneurial marketing: a construct for integrating emerging entrepreneurship and marketing perspectives. Journal of Marketing Theory and Practice, 10(4), 119.

Miles, M. P., \& Darroch, J. (2006). Large firms, entrepreneurial marketing processes, and the cycle of competitive advantage. European Journal of marketing.

Miller, D. (1983). The correlates of entrepreneurship in three types of firms. Management Science, 29(7), 770791.

Morrish, S. C., \& Jones, R. (2020). Post-disaster business recovery: An entrepreneurial marketing perspective. Journal of Business Research, 113, 83-92.

Martin, D. M. (2009). The entrepreneurial marketing mix. Qualitative market research: an international journal.

Mort, G. S., Weerawardena, J., \& Liesch, P. (2012). Advancing entrepreneurial marketing. European Journal of Marketing.

Morrish, S., \& Gilmore, A. (2011). Entrepreneurial and SME marketing. Journal of Research in Marketing and Entrepreneurship.

Martin, D.M., 2009. "The entrepreneurial marketing mix", Qualitative Market Research: An International Journal 12, No. 4, pp. 391-403.

Morris, D. W., \& Diffendorfer, J. E. (2004). Reciprocating dispersal by habitat-selecting white-footed mice. Oikos, 107(3), 549-558.

Miller, D. (1983). The correlates of entrepreneurship in three types of firms. Management Science, 29(7), 770791.

Miles, M. P., \& Darroch, J. (2006). Large firms, entrepreneurial marketing processes, and the cycle of competitive advantage. European Journal of marketing.

Morris, M.H., M., Schindehutte and R.W., La Forge, 2004. "The emergence of entrepreneurial marketing: nature and meaning". Editor: Harold P. Welsch. Entrepreneurship: The Way Ahead.Routledge. pp. 91-115.

Morrish, S. and J., Deacon, 2009. "Entrepreneurial marketing: a comparative case study of 42below vodka and penderyn whisky". http://www.swinburne.edu.au/lib/ir/onlineconferences/agse2009/000140. pdf,11.06.2010.

Nikfarjam, A., \& Zarifi, S. (2015). Exploring the effects of entrepreneurial marketing factors on SMEs. Uncertain Supply Chain Management, 3(4), 333-338.

Nwankwo, C. A., \& Kanyangale, M. (2020). Deconstructing entrepreneurial marketing dimensions in small and medium-sized enterprises in Nigeria: a literature analysis. International Journal of Entrepreneurial Venturing, 12(3), 321-341.

Porter, M. E. (1980). Industry structure and competitive strategy: Keys to profitability. Financial Analysts Journal, 36(4), 30-41. 
Patton, M. Q. (2002). Two decades of developments in qualitative inquiry: A personal, experiential perspective. Qualitative Social Work, 1(3), 261-283.

Rosa, P., Carter, S., \& Hamilton, D. (1996). Gender as a determinant of small business performance: Insights from a British study. Small Business Economics, 8(6), 463-478.

Sodhi, R. S., \& Bapat, D. (2020). An Empirical Study of the Dimensions of Entrepreneurial Marketing. Academy of Marketing Studies Journal, 24(1), 1-7.

Shaw, E. (2004). Marketing in the social enterprise context: is it entrepreneurial?. Qualitative Market Research: An International Journal.

Stokes, D. (2000). Entrepreneurial marketing: a conceptualization from qualitative research. Qualitative Market Research: An International Journal.

Seuwandhi B. Ranasinghe. (2011 Factors Contributing to the Success of Women Entrepreneurs in Sri Lanka .Sri Lanka Journal of Advanced Social Studies Vol. 1 - No. 2

Strauss, S. (2004), "Globalization is good for (small) business," USA Today, available at: www.

usatoday.com/money/smallbusiness/columnist/strauss/2004-05-17-globalization_x. htm(c20041881) (accessed 25 September 2006).

Shaw, E. (2004). Marketing in the social enterprise context: is it entrepreneurial? Qualitative Market Research: An International Journal.

Shane, S., \& Venkataraman, S. (2000). The promise of entrepreneurship as a field of research. Academy of Management Review, 25(1), 217-226.

Stokes, D. (2000b). Putting entrepreneurship into marketing: the processes of entrepreneurial marketing. Journal of Research in Marketing and Entrepreneurship.

Sajjad, M., Kaleem, N., Chani, M.I. and Ahmed, M. (2020), "Worldwide role of women entrepreneurs in economic development", Asia Pacific Journal of Innovation and Entrepreneurship, Vol. 14 No. 2, pp. 151160. https://doi.org/10.1108/APJIE-06-2019-0041

Creswell, J. W., Plano Clark, V. L., Gutmann, M. L., \& Hanson, W. E. (2003). An expanded typology for classifying mixed methods Research into designs. A. Tashakkori y C. Teddlie, Handbook of Mixed Methods in Social and Behavioral Research, 209-240.

Whalen, P., Uslay, C., Pascal, V. J., Omura, G., McAuley, A., Kasouf, C.J.,\&Gilmore, A.(2016). Anatomy of competitive advantage: towards a contingency theory of entrepreneurial marketing. Journal of Strategic Marketing 24(1), 5-16.

Watson, J. (2003). Failure rates for female-controlled businesses: are they any different? Journal of Small Business Management, 41(3), 262-277.

"World Bank (2011). The World Bank Annual Report 2011: Year in Review. Washington, DC. (C) World Bank. https://openknowledge.worldbank.org/handle/10986/2378 License: CC BY 3.0 IGO."

Yang, M., \& Gabrielsson, P. (2017). Entrepreneurial marketing of international high-tech business-to-business new ventures: A decision-making process perspective. Industrial Marketing Management, 64, 147-160. 